\title{
Muscle strength and functional capacity of elderly people engaged in two types of strength training
}

\author{
Força muscular e capacidade funcional de idosos praticantes de dois \\ exercícios contra resistência
}

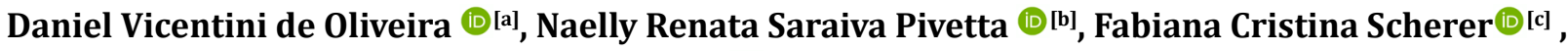 \\ José Roberto Andrade do Nascimento Júnior [D[d]*
}

[a] Centro Universitário de Maringá (UNICESUMAR), Maringá, PR, Brazil

[b] Universidade Estadual de Campinas (UNICAMP), Campinas, SP, Brazil

[c] Universidade Estadual de Londrina (UEL), Londrina, PR, Brazil

[d] Universidade Federal do Vale do São Francisco (UNIVASF), Petrolina, PE, Brazil

\begin{abstract}
Introduction: Regular physical activity is one of the main ways of avoiding compromised functional capacity and gaining muscle mass. Objective: investigate the differences in muscle strength and functional capacity of elderly people engaged in two types of strength exercises. Method: a cross-sectional study of 80 seniors of both sexes, 40 of whom engaged in weight training and 40 from the Fitness Zone in the city of Maringá, Paraná, state. A sociodemographic questionnaire, the sitting-rising and elbow flexion tests, and the functional capacity tests of the Latin American Development Maturity Group (GDLAM) were applied. The data were analyzed using the Shapiro-Wilk, Mann-Whitney "U" and Spearman's correlation tests ( $p<0.05)$. Results: Most seniors who performed well in the sitting and rising test, rising from a chair and moving around the house and rising from the dorsal decubitus position engaged in weight training $(\mathrm{p}=0.001)$. Those engaged in weight training exhibited better upper limb strength and functional capacity in all the tests performed $(\mathrm{p}<0.05)$. Muscle strength is inversely related to functional capacity, that is, the better the result in
\end{abstract}

*DVO: PhD, e-mail: d.vicentini@hotmail.com ORCID NRSP: MS, e-mail: naellypivetta@outllok.com ORCID FCS: PhD, e-mail: schererfaby@hotmail.com ORCID JRANJ: PhD, e-mail: jroberto.jrs01@gmail.com ORCID 
the upper and lower limb muscle strength tests, the better the functional capacity of the elderly engaged in weight training. Conclusion: According to the results obtained, older people who engage in weight training display better upper limb strength and functional capacity than seniors from the Fitness Zone.

Keywords: Aging. Motor Activity. Muscles. Training.

\section{Resumo}

Introdução: A atividade física regular é uma das principais formas de evitar a capacidade funcional comprometida e o ganho de massa muscular. Objetivo: investigar as diferenças na força muscular e na capacidade funcional de idosos praticantes de dois tipos de exercícios contra resistência. Método: estudo transversal, realizado com 80 idosos de ambos os sexos, sendo 40 praticantes de musculação e 40 praticantes de exercícios nas Academias da terceira idade (ATI) no município de Maringá, Paraná. Foi aplicado um questionário sociodemográfico, os testes Sentar e Levantar, Flexão de cotovelo, e os testes de capacidade funcional do Grupo de Desenvolvimento Latino Americano para Maturidade (GDLAM). Os dados foram analisados pelos testes Shapiro-Wilk; "U" de Mann-Whitney e correlação de Spearman $(p<0,05)$. Resultados: A maior proporção de idosas com nível bom para os testes levantar da posição sentada, levantar da cadeira e mover-se pela casa, $e$ levantar da posição de decúbito dorsal, praticava musculação $(p=0,001)$. Os idosos praticantes de musculação apresentaram melhor força muscular de membros superiores e melhor capacidade funcional em todos os testes realizados $(p<0,05)$. A força muscular está inversamente relacionada à capacidade funcional, ou seja, quanto melhor o resultado nos testes de força muscular de membros superiores e inferiores melhor a capacidade funcional do idoso praticante de musculação. Conclusão: De acordo com os resultados obtidos, conclui-se que idosos praticantes de musculação possuem melhor força muscular de membros superiores e melhor capacidade funcional do que idosos praticantes de exercícios nas ATI.

Palavras-chave: Envelhecimento. Atividade Motora. Músculos. Treinamento.

\section{Introduction}

Aging is a dynamic progressive process, characterized by morphofunctional alterations in all body tissues [1]. These changes culminate in a decline in favorable responses to stressor agents, making the body vulnerable and susceptible to injury [1]. Loss of muscle mass, bone mass, flexibility and strength as well as cognitive impairment are among the changes that tend to worsen the overall health status of individuals and affect their functional capacity $[2,3]$.

Functional capacity includes physical and mental skills essential to maintaining total independence and autonomy, for both simple and complex activities [4]. Compromised functional capacity affects the elderly because it increases dependence, vulnerability and the risk of depression, leads to higher health system costs and more hospitalizations and affects the family, since care is required to perform the activities of daily living $[4,5]$.

In this respect, functional capacity is a new method to assess elderly health [6]. This assessment is particularly important because functional impairment can be a result of chronic diseases, polypharmacy and, primarily, physical inactivity [7].

Regular physical activity is one of the main ways of avoiding compromised functional capacity and gaining muscle mass [2]. The opposite is also true, in that physical inactivity is a major contributor to reduced muscle and bone mass, worsens cardiorespiratory conditioning and increases risk of frailty and physical dependence. Moreover, it is associated with mortality and morbidity in old age [2].

According to the American College of Sports Medicine (ACSM), physical activity is defined as any bodily movement produced by skeletal muscles that results in energy expenditure above resting (basal) levels. Strength training specifically targets hypertrophy and/or increasing muscle mass [8].

Among the most common physical activities is weight training, characterized by planned, structured and repetitive bodily movements [8]. Weight training can be performed at gyms, and despite its popularity, is relatively costly for some individuals. For this and other 
reasons, Elderly Gyms (EGs) were created [9]. EGs are located in the open air, generally in the squares of the main neighborhoods of a city and are free to use [9].

Thus, given that functional impairment occurs in aging and that physical inactivity is a risk inherent to morbidity and mortality among the elderly, the purpose of the present study was to investigate the differences in muscle strength and functional capacity of seniors engaged in two types of strength training. The hypothesis is that elderly people engaged in strength training at conventional gyms, that is, weight training, exhibit better muscle strength and functional capacity than those belonging to EGs.

\section{Method}

This cross-sectional observational study, conducted between February and June 2017, consisted of a nonprobability sample of 80 seniors, 40 engaged exclusively in weight training at 12 private gyms, and 40 in physical exercises at 12 EGs, all located in different parts (north, south, east and west regions) of Maringá, Paraná (PR) state, Brazil.

The sample was selected by convenience and both groups included elderly individuals (60 years or older) engaged exclusively in one physical exercise modality (weight training or EG exercises). The exclusion criteria were walking with the aid of an assistive device and visual, cognitive and auditory impairments that would hinder understanding the questionnaires applied and performance of the specific tests.

This study was approved by the Research Ethics Committee of the Metropolitan Faculty of Maringá (FAMMA), under protocol number 2.190.433/2017. After permission was obtained from the Department of Sports and Leisure of Maringá and written informed consent from the seniors, trained researchers initiated data collection.

The same assessments were performed for both groups. A standardized questionnaire was used to assess the sociodemographic and health status, and the following sociodemographic variables were collected: age ranges ( 60 to 69 years; 70 to 79 years and 80 years or older); race (white, black, Asiatic and Indian); schooling (never studied, incomplete elementary, elementary graduate, secondary graduate and university graduate); retired (yes or no); occupation (active or inactive); monthly income in minimum wages (MW) for 2017 (<1
$\mathrm{MW}, 1$ to $2 \mathrm{MW}$ and $>2 \mathrm{MW}$ ) and marital status (conjugal companion or no conjugal companion).

The health status and exercise variables were presence of noncommunicable chronic diseases (none; one; two or more); history of falls in the six months before the study (yes; no); time engaged in weight training/ EG exercises (< six months; six months to two years; $>$ two years), weekly frequency of weight training/EG exercises (once or twice; three times or more).

Functional capacity was assessed by the Latin American Development Maturity Group (GDLAM) tests10,11, as follows: 10 -meter walk test (10MWT), rising from a sitting position (RSP), rising from a ventral decubitus position (RVDP), putting on and taking off a t-shirt (PTT), and rising from a chair and moving around the house (RCMH). These tests were measured in seconds and values calculated using the following mathematical formula (GDLAM index-GI):

$$
\mathrm{GI}=\frac{[(10 \mathrm{MWT}+\mathrm{RSP}+\mathrm{RVDP}+\mathrm{PTT} \times 2]+\mathrm{RCMH}}{4}
$$

Next, functional capacity was classified according to GDLAM, which ranges from "weak" to "very good" in each test $[10,11]$.

Muscle strength was assessed using two of the Rikli Jones Senior Fitness Tests [12]: forearm flexion (upper limb muscle strength and resistance) and sitting and rising from a chair (lower limb muscle strength and resistance).

In the forearm flexion test, the seniors were instructed to sit in a chair with back support, and $43 \mathrm{~cm}$ between the floor and the seat. Each individual performed the maximum number of possible elbow flexions and extensions for 30 seconds holding a $2 \mathrm{~kg}$ (for women) or $4 \mathrm{~kg}$ (for men) dumbbell in the dominant upper limb. In the sitting and rising from a chair test, the individuals rose and sat in a chair (with the same characteristics described above), performing the maximum number of repetitions possible in 30 seconds, with arms crossed at chest level [12]. All the complete repetitions in both tests were recorded by the researchers.

The data were analyzed using the SPSS program, version 22.0. Descriptive analyses of the categorical variables were conducted with frequency and percentage values. The Shapiro-Wilk test was applied to verify normality of the numerical variables and since the data were not normally distributed, the median (Md) and quartiles (Q1 and Q3) were used to characterize 
the results. For inferential statistics, the chi-squared test was applied to compare the proportion of seniors from both groups as a function of sociodemographic, health status and muscle strength variables. The MannWhitney U test was used to compare muscle strength and functional capacity as a function of the type of exercise engaged in, and Spearman's correlation coefficient to determine the correlation between the two variables. The significance level was set at $\mathrm{p}<0.05$.

\section{Results}

Comparison between the proportion of elderly engaged in EG exercises as a function of sociodemographic variables (Table 1) found no significant difference $(p$ $>0.05$ ) in any of the variables. These results indicate intergroup homogeneity in relation to sociodemographic variables.

Table 1 shows a comparison between health status and physical exercise, according to the type engaged in. It was found that $76.9 \%$ of the elderly with two or more diseases engaged in EG exercises ( $p=0.027)$. There was a larger proportion of seniors (73.3\%) who exercised once or twice a week at the EGs ( $p=0.045)$.

Table 1 - Health status and physical exercises, according to the type of exercise engaged in by the seniors. Maringá, Paraná, Brasil, 2017

\begin{tabular}{|c|c|c|c|c|}
\hline \multirow{3}{*}{ VARIABLES } & \multicolumn{2}{|c|}{ Type of exercise } & \multirow{3}{*}{$\mathrm{X} 2$} & \multirow{3}{*}{$\mathbf{P}$} \\
\hline & $\begin{array}{l}\text { Weight training } \\
\quad(n=40)\end{array}$ & $\begin{array}{c}\text { EG } \\
(n=40)\end{array}$ & & \\
\hline & $f(\%)$ & $f(\%)$ & & \\
\hline \multicolumn{5}{|l|}{$\begin{array}{l}\text { Number of } \\
\text { diseases }\end{array}$} \\
\hline None & $28(58.3)$ & $20(41.7)$ & & \\
\hline 1 & $9(47.4)$ & $10(52.6)$ & 4.863 & $0.027^{\star}$ \\
\hline $\begin{array}{l}2 \text { or } \\
\text { more }\end{array}$ & $3(23.1)$ & $10(76.9)$ & & \\
\hline \multicolumn{5}{|l|}{$\begin{array}{l}\text { History } \\
\text { of falls }\end{array}$} \\
\hline Yes & $4(40.0)$ & $6(60.0)$ & \multirow{2}{*}{0.457} & \multirow{2}{*}{0.499} \\
\hline No & $36(51.4)$ & $34(48.6)$ & & \\
\hline \multicolumn{5}{|l|}{$\begin{array}{l}\text { Time } \\
\text { engaged in } \\
\text { the activity }\end{array}$} \\
\hline $\begin{array}{l}\text { Less } \\
\text { than } 6 \\
\text { months }\end{array}$ & $6(42.9)$ & $8(57.1)$ & & \\
\hline
\end{tabular}

(to be continued)

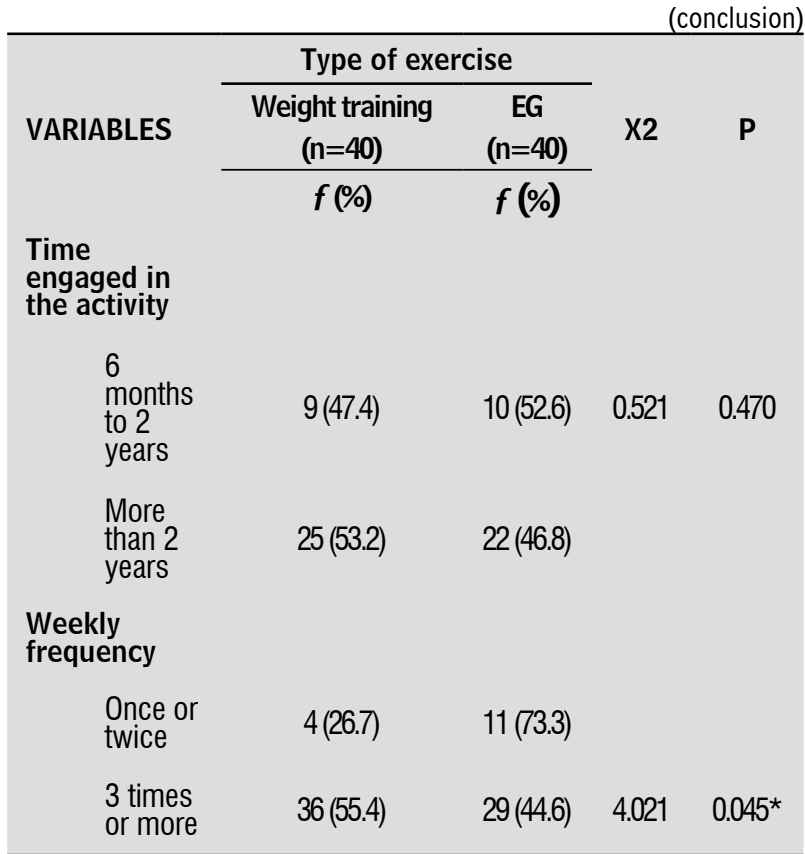

Note: Statistical significance of $p<0.05$ (chi-squared test). EG: elderly gym.

More than half the elderly (56.5\%) with a "good" result in the sitting and rising test exercised at EGs, and $83.3 \%$ obtained a "fair" level in the elbow flexion and extension tests $(\mathrm{p}<0.05)$. Most of the elderly with a "good" level in the RSP, RCMH and RVDP tests engaged in weight training $(\mathrm{p}=0.001)$ (Table 2$)$.

Table 2 - Comparison between the proportion of seniors engaged in weight training and EG exercises as a function of functional capacity and muscle strength. Maringá, Paraná, Brazil, 2018

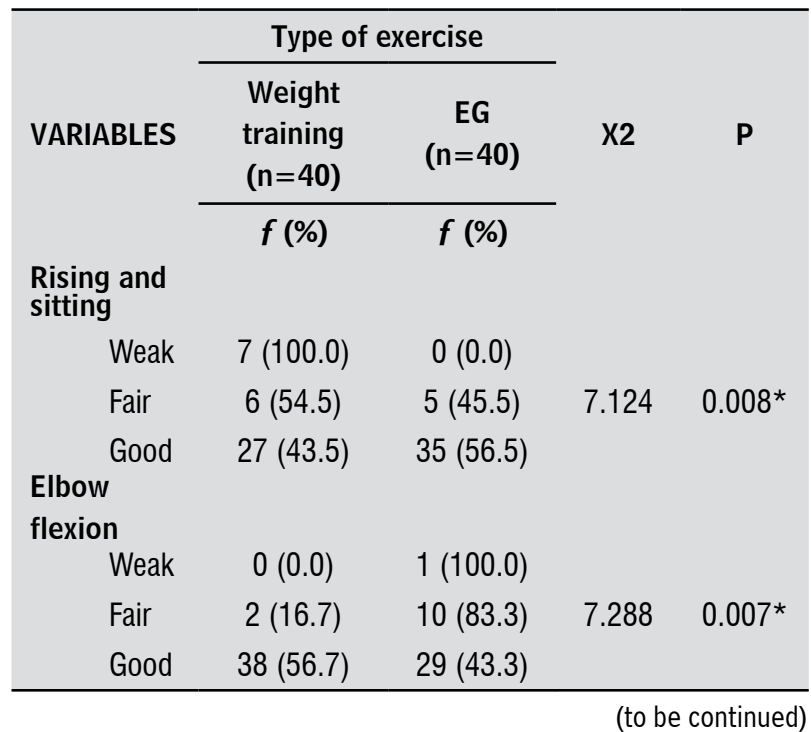




\begin{tabular}{|c|c|c|c|c|}
\hline & & & & conclusion) \\
\hline & Type of & tercise & & \\
\hline VARIABLES & $\begin{array}{l}\text { Weight } \\
\text { training } \\
(n=40)\end{array}$ & $\begin{array}{c}E G \\
(n=40)\end{array}$ & $\mathrm{X} 2$ & $\mathbf{P}$ \\
\hline & $f(\%)$ & $f(\%)$ & & \\
\hline 10MWT & & & & \\
\hline Weak & 39 (49.4) & $40(50.6)$ & 1.013 & 0.314 \\
\hline Fair & $1(100.0)$ & $0(0.0)$ & & \\
\hline RSP & & & & \\
\hline Weak & $4(15.4)$ & $22(84.6)$ & & \\
\hline Fair & $9(37.5)$ & 15 (62.5) & 31.218 & $0.001^{*}$ \\
\hline Good & $27(90.0)$ & $3(10.0)$ & & \\
\hline $\mathrm{RCMH}$ & & & & \\
\hline Weak & $1(4.5)$ & $21(95.5)$ & & \\
\hline Fair & $17(47.2)$ & 19 (52.8) & 39.590 & $0.001^{*}$ \\
\hline Good & $22(100.0)$ & $0(0.0)$ & & \\
\hline RVDP & & & & \\
\hline Weak & $22(39.3)$ & $34(60.7)$ & & \\
\hline Fair & $12(66.7)$ & $6(33.3)$ & 10.405 & $0.001^{*}$ \\
\hline Good & $6(100.0)$ & $0(0.0)$ & & \\
\hline PTT & & & & \\
\hline Weak & 33 (51.6) & $31(48.4)$ & & \\
\hline Fair & $2(18.2)$ & $9(81.8)$ & 0.349 & 0.555 \\
\hline Good & $5(100.0)$ & $0(0.0)$ & & \\
\hline GI & & & & \\
\hline Weak & 33 (45.2) & $40(54.8)$ & 7671 & $\cap \cap 06^{*}$ \\
\hline Fair & 7 (100.0) & $0(0.0)$ & 1.011 & 0.000 \\
\hline
\end{tabular}

Note: 10MWT: 10-meter walk test; RSP: rising from a sitting position; RVDP: rising from a ventral decubitus position; RCMH: rising from a chair and moving around the house; PTT: putting on and taking off a t-shirt; GI: GDLAM index. *Statistical significance of $p$ $<0.05$ (chi-squared test for proportions).

Table 3 presents a comparison between the muscle strength and functional capacity of seniors as a function of exercise type.

Table 3 shows a significant difference $(\mathrm{p}<0.05)$ in all the tests, except for the sitting and rising test $(\mathrm{p}=$ 0.498). These results demonstrate that seniors engaged in weight training exhibited better upper limb strength and enhanced functional capacity in all the tests conducted. Table 4 presents the correlation between functional capacity and muscle strength for the elderly individuals engaged in weight training.

Table 3 - Comparison between the muscle strength and functional capacity of seniors as a function of exercise type. Maringá, Paraná, Brazil, 2017

\begin{tabular}{|c|c|c|c|}
\hline \multirow{3}{*}{ VARIABLES } & \multicolumn{2}{|c|}{ Type of exercise } & \multirow{3}{*}{$\mathbf{P}$} \\
\hline & $\begin{array}{l}\text { Weight } \\
\text { training } \\
(n=40)\end{array}$ & $\begin{array}{c}E G \\
(n=40)\end{array}$ & \\
\hline & Md (Q1 and Q3) & Md (Q1 and Q3) & \\
\hline \multicolumn{4}{|l|}{$\begin{array}{l}\text { Muscle } \\
\text { Strength }\end{array}$} \\
\hline $\begin{array}{l}\text { Sitting and } \\
\text { rising }\end{array}$ & $18.0(15.0 ; 23.0)$ & $19.0(17.0 ; 21.0)$ & 0.498 \\
\hline Elbow flexion & $26.0(23.3 ; 28.0)$ & $20.0(18.0 ; 22.0)$ & $0.001^{*}$ \\
\hline \multicolumn{4}{|l|}{$\begin{array}{l}\text { Functional } \\
\text { Capacity }\end{array}$} \\
\hline 10MWT (m) & $11.6(10.6 ; 13.2)$ & $16.0(15.2 ; 16.6)$ & $0.001^{*}$ \\
\hline RSP (sec.) & $9.2(8.2 ; 10.2)$ & $12.1(11.0 ; 13.2)$ & $0.001^{*}$ \\
\hline RCMH (sec.) & $38.6(36.8 ; 40.1)$ & $43.6(42.0 ; 45.2)$ & $0.001^{*}$ \\
\hline RVDP (sec.) & $5.1(4.1 ; 6.0)$ & $6.4(5.3 ; 7.6)$ & $0.001^{*}$ \\
\hline PTT (sec.) & $13.2(12.1 ; 15.1)$ & $14.9(13.7 ; 15.4)$ & $0.007^{*}$ \\
\hline Gl (score) & $29.6(27.6 ; 30.5)$ & $35.6(34.1 ; 36.3)$ & $0.001^{*}$ \\
\hline
\end{tabular}

Note: * Significant difference: $\mathrm{p}<0.05-$ Mann-Whitney U test. $10 \mathrm{MWT}=10$-meter walk test; RSP = rising from a sitting position; $\mathrm{RCMH}=$ rising from a chair and moving around the house; RVDP = rising from a ventral decubitus position; PTT = putting on and taking off a t-shirt; GI = GDLAM index; m: meters; sec.: seconds.

Table 4 shows the following significant correlations ( $p$ $<0.05$ ) between functional capacity and muscle strength: RS and RSP $(r=-0.34)$, PTT $(r=-0.30)$ and GI $(r=-0.53)$; EF and RSP ( $r=-0.53)$, RCMH ( $r=-0.47)$, RVDP ( $r=-0.40)$ and GI $(r=-0.48)$. These results indicate that muscle strength is inversely related to functional capacity, that is, the better the result in upper and lower limb muscle strength, the better the functional capacity of seniors engaged in weight training. Table 5 demonstrates the correlation between the functional capacity and muscle strength of elderly engaged in exercises at the EGs. 
Table 4 - Correlation between the muscle strength and functional capacity of seniors engaged in weight training. Maringá, Paraná, Brazil, 2017

\begin{tabular}{|c|c|c|c|c|c|c|c|c|}
\hline \multirow{2}{*}{ VARIABLES } & \multicolumn{2}{|c|}{ Muscle Strength } & \multicolumn{6}{|c|}{ Functional Capacity } \\
\hline & SR & EF & 10MWT & RSP & $\mathrm{RCMH}$ & RVDP & PTT & GI \\
\hline SR & & $0.40^{\star}$ & 0.24 & $-0.34^{*}$ & -0.26 & -0.28 & $-0.30^{*}$ & $-0.53^{*}$ \\
\hline EF & & & 0.17 & $-0.53^{*}$ & $-0.47^{*}$ & $-0.40^{*}$ & -0.28 & $-0.48^{*}$ \\
\hline 10MWT & & & & -0.06 & 0.06 & -0.06 & 0.06 & $0.37^{*}$ \\
\hline RSP & & & & & $0.41^{*}$ & 0.13 & 0.09 & $0.44^{*}$ \\
\hline $\mathrm{RCMH}$ & & & & & & 0.22 & $0.35^{\star}$ & $0.55^{\star}$ \\
\hline RVDP & & & & & & & $0.42^{\star}$ & $0.63^{*}$ \\
\hline PTT & & & & & & & & $0.70^{*}$ \\
\hline Gl & & & & & & & & \\
\hline
\end{tabular}

Note: * Significant Correlation $-\mathrm{p}<0.05 . \mathrm{SR}=$ sitting and rising; $\mathrm{EF}=$ elbow flexion; $10 \mathrm{MWT}=10$-meter walk test; $\mathrm{RSP}=$ rising from a sitting position; $\mathrm{RCMH}=$ rising from a chair and moving around the house; RVDP = rising from the ventral decubitus position; PTT = putting on and taking off a t-shirt; $\mathrm{Gl}=$ GDLAM index.

There was a significant correlation $(\mathrm{p}<0.05)$ only between SR and the 10MWT ( $r=0.40)$, indicating that the greater the lower limb muscle strength, the farther the distance walked by the seniors (Table 5).

Table 5 - Correlation between the muscle strength and functional capacity of elderly individuals engaged in exercises at EGs. Maringá, Paraná, Brazil, 2017

\begin{tabular}{|c|c|c|c|c|c|c|c|c|}
\hline \multirow{2}{*}{ VARIABLES } & \multicolumn{2}{|c|}{ Muscle Strength } & \multicolumn{6}{|c|}{ Functional Capacity } \\
\hline & SR & $\mathrm{EF}$ & 10MWT & RSP & RCMH & RVDP & PTT & GI \\
\hline SR & & 0.08 & $0.40^{*}$ & 0.02 & -0.14 & -0.13 & 0.25 & 0.11 \\
\hline $\mathrm{EF}$ & & & -0.20 & 0.17 & -0.12 & -0.03 & -0.07 & -0.12 \\
\hline 10MWT & & & & 0.09 & 0.13 & -0.09 & 0.07 & $0.40^{*}$ \\
\hline RSP & & & & & 0.04 & -0.18 & 0.08 & $0.39 *$ \\
\hline $\mathrm{RCMH}$ & & & & & & -0.01 & 0.01 & $0.39 *$ \\
\hline RVDP & & & & & & & 0.04 & $0.43^{*}$ \\
\hline PTT & & & & & & & & $0.51^{*}$ \\
\hline $\mathrm{Gl}$ & & & & & & & & \\
\hline
\end{tabular}

Note: *Significant Correlation $-\mathrm{p}<0.05 . \mathrm{SR}=$ sitting and rising; $\mathrm{EF}=$ elbow flexion; 10MWT $=10$-meter walk test; $\mathrm{RSP}=$ rising from a sitting position; $\mathrm{RCMH}=$ rising from a chair and moving around the house; RVDP = rising from the ventral decubitus position; PTT = putting on and taking off a t-shirt; GI = GDLAM index.

\section{Discussion}

The main findings of this study are: weight training group participants: - association between "good" classification and rising from a sitting position (lower limb functional capacity), rising from a chair and moving around the house (agility and balance, in life situations) and rising from a ventral decubitus position (ability of the individual to rise from the floor); - association with "fair" functional capacity; - muscle strength inversely related to functional capacity. b) EG group participants: the greater the lower limb muscle strength, the longer the distance walked (the higher the gait speed). Thus, in general, the weight training group showed better upper limb muscle strength and superior functional capacity.

The EG participants suffered from more diseases (two or more), suggesting a possible relation between EG physical activity and number of diseases. In this 
respect, EGs were implemented in order to decrease physical inactivity and reduce the indices of chronic degenerative diseases. The EGs were implemented in Maringá, as part of the Public Health Policy of the Healthy Maringá Program, near the Basic Health Units to facilitate the work of physical education professionals and the Family Health teams. Thus, interaction between the policy of the National Health System (SUS)/ EG/professionals and the community seems to promote greater participation of individuals with diseases in the EGs. Corroborating this, Burton et al. [13] conducted a systematic review on the motivators and barriers to elderly participation in resistance training and found that the most frequent reasons for initiating and continuing resistance training were related to health, such as increasing strength and balance and improving health and physical function, with a view to extending life expectancy, preventing physical impairment, reducing the risk of falls and enhancing muscle tone, among others.

EG participants exercised less frequently (once or twice a week) than those engaged in weight training ( $p=$ 0.045). Although the EG activities are free of charge, the participants seem to be less committed than the weight training group. This may be due to the fact that the EG individuals have more diseases and participate in additional disease-related activities, including taking part in meetings for patients with the same diseases, such as The National Program for Hypertension and Diabetes (Hiperdia) and others; have more medical visits and undergo more examinations. In addition, the income factor may interfere in exercise frequency. This interaction is controversial in the literature [14-16]. Some specialists $[14,15]$ report that a better socioeconomic condition favors regular physical activity.

However, this diverges, in part, from that reported by Oliveira et al. [16], who compared weekly frequency of physical activity in three modalities (water aerobics, weight training and EG) and found that EG participants exhibited greater frequency (four or more times a week) and consisted of more individuals earning one to two minimum monthly wages. The weight training group also obtained a median frequency (three times a week) and a slightly higher income than the others.

However, the proportion between the two modalities shows a higher number of seniors engaged in the activities three or more times a week. This demonstrates their possible awareness of the importance of regular physical activity and its health benefits. Thus, the elderly participants of the modalities comply with World Health Organization recommendations [17], which suggests a minimum of twice a week for strength training. This recommendation is within the minimum guideline of 150 minutes of physical activity per week.

In the rising and sitting test [12], there was a significant difference in favor of EG participants, $56.5 \%$ of whom were classified as good. In the present study, intragroup performance revealed that most of the weight training individuals exhibited good results. Normal lower limb strength for age[12] was found in most of the seniors, suggesting that they can execute their daily tasks independently. Santos et al. [18] aimed to identify the number of repetitions needed in the sitting and rising from a chair test to estimate functional impairment. The authors found that the cutoff point to determine functional disability in the basic activities of daily living (ADL) was $<10$ repetitions (men) and $<9$ (women) and $<14$ (men) and $<10$ (women) for the instrumental activities of daily living (IADL). They concluded that lower limb strength can be used as a predictor of functional impairment in ADL and IADL.

In this respect, it is also important to consider that the "sitting and rising" test shows good correlation with the one repetition maximum test in the leg press $(\mathrm{r}=$ 0.78 for men and $r=0.71$ for women) [19]. Thus, weight training equipment can be used to assess the performance of seniors. When they perform poorly in the test, training can be modified/intensified to obtain better results. Bean et al. [20] indicated that older people with limited mobility who participated in a 16-week training program increased muscle power in the leg press by $10 \%$ more than in a traditional strength training program, but both groups improved equally in muscle strength and mobility.

Another aspect that should be considered when analyzing functional capacity in seniors, primarily in the rising and sitting test, is body mass index (BMI). In a study aimed at investigating the association between the BMI and functional aptitude levels of 1806 elderly participants of the Elderly in Motion program in Curitiba, Paraná state, Vagetti et al. [21] found that obese seniors were more likely to display poor functional aptitude, including in the rising and sitting test. Thus, although our study observed few seniors with poor performance in the rising and sitting test, it is suggested that future tests include BMI analysis when functional test performance is assessed.

With respect to upper limbs, a large portion of the elderly from both groups obtained a good result in the elbow flexion test, with better indices in the weight training group. This better performance is likely due to the fact 
that the group used exercises involving external loads (weights), in contrast to EG individuals, who used only body weight to exercise with the equipment. The good performance in this and the rising and sitting test suggests autonomy in many activities of daily living, such as carrying shopping bags, walking, riding a bicycle, etc.

The elbow flexion test, validated by Riki and Jones [12], shows a good correlation with the one repetition maximum test in the supine position $(\mathrm{r}=0.84$ for men and $r=0.79$ for women) [19]. Thus, the supine device can be used in weight training gyms to assess the performance of seniors and if it is poor, emphasize training on this equipment and in the upper limb muscles, primarily the pectoral, deltoid and triceps muscles.

Gait velocity (10MWT) revealed that $98.75 \%$ of both groups were classified as weak, a finding similar to that reported by Oliveira et al. ${ }^{16}$. However, in experimental studies with strength and/or flexibility training, a significant improvement was found in all the GDLAM protocol tests, and particularly in the 10MWT test [22-25].

What differed in both results (improved 10MWT test and the weak result) was the previous participation in physical activities. In our study and that of Oliveira et. [16], the seniors had been engaged in the modality twice a week for at least three months. In the study by King et al. [24], the eligibility criterion was that the elderly individuals were not regularly active more than twice a week during the six months before assessment/onset of the study. In a study by Vale et al. [23], the elderly had not engaged in physical exercise for at least six months. Likewise, in another study by Vale et al. [22], the seniors had not taken part in programs and/or engaged in strength and flexibility exercises for at least three months before the program. In the investigation by Schlight et al. [25], elderly subjects were not involved in strength training. Thus, seniors exposed to exercise may be less susceptible to changes over time and in our study the exercises conducted were most likely not sufficient to cause satisfactory changes in the elderly, thereby requiring corrections/adaptations with a rise in load during the exercises.

As such, it is suggested that during weight training programs greater emphasis be paid to the quadriceps, ischiotibial and hip flexor muscles responsible for gait, with an increase in weight. The EG results may have occurred due to the absence of external weights, since in most of the devices, the exercises are performed only with the body weight or that of the equipment itself. It is important that performance in this test (10MWT) improve, since good results indicate greater safety for seniors, for example, when crossing the street [26].

The result obtained for lower limb strength differed between the tests. In the rising and sitting test in the Senior Fitness tests, the EG seniors obtained a better result (56.5\% good). In the GDLAM rising from a sitting position test, seniors obtained a less satisfactory outcome. A total of $67.5 \%$ of the weight training participants reached a good level, while more than half of the EG group (55\%) were considered weak. In the GDLAM rising from a sitting position test, Oliveira et al. [16] observed that seniors from the water aerobics and EG groups obtained similar results and were classified as fair, whereas the weight training group obtained a weak result. This demonstrates the need to emphasize the development of lower limb strength during training, since it is the first to decline and is the neuromotor component that decreases most with aging ( $-1.4 \% /$ year, that is $14 \% /$ decade) [27]. This is a normal result of aging and is related to the lack of physical activity, loss of muscle fiber, protein synthesis and mitochondrial function [28, 29].

In the RCMH test in the present study, which aimed to assess the agility and balance of the seniors in daily situations [26], EG participants (52.5\%) obtained a weak level and their weight training counterparts were classified as good. These results differed from those reported by Oliveira et al. [16], where the seniors from the EGs were classified as very good, with better results than those of the weight training and water aerobics groups. In the present study, the weight and strength training may have improved performance in this test.

For the RVDP variable, both programs obtained a weak result (weight training $=55 \%, \mathrm{EG}=85 \%$ ). Despite this result, the weight training group performed better than their EG counterparts. The results obtained by Oliveira et al. [16] were similar. Thus, despite the lack of satisfactory results, the better performance by the weight training group can be justified by the fact that they used all their body muscles, which requires a certain amount of strength and control [26]. It is important to underscore that weight training aims at improving strength and resistance, through the use of specialized equipment and extra weights. This test reflects the functional capacity of seniors and is related to greater risk of death [30], demonstrating the importance of intensifying training in order to obtain better results, but in a manner that is enjoyable to those involved.

The present study exhibits the following limitations: a cross-sectional design, which precludes establishing cause and effect of the variables analyzed; b) the data 
collection sites were diverse and may have resulted in different measurements and classifications, and c) the use of a non-probability sample, that is, the absence of a sampling calculation. The strong points should also be mentioned: a) the study was conducted in community settings and b) the modalities explored here are the most widely used by the elderly population in the city assessed, according to the authors' experience. It is suggested that new studies be carried out, preferably longitudinal, to monitor health variables, such as the muscle strength and functional capacity of seniors engaged in different physical exercise modalities.

\section{Conclusion}

According to the results obtained, it can be concluded that seniors engaged in weight training exhibit better upper limb muscle strength and enhanced functional capacity than their EG counterparts. The practical applicability of this study is to help administrators/ public health professionals make decisions in terms of the interventions needed to preserve the functional status of the elderly, in order to improve their performance in daily activities and prolong their autonomy and independence.

\section{Acknowledgments}

This study was conducted with the support of Fundação de Amparo à Pesquisa e Inovação do Estado de Santa Catarina, FAPESC / Brazil (PAP UDESC, Public Call No. 04/2018, Granting Term 2019TR658).

\section{References}

1. Freitas EVD, Py L. Tratado de Geriatria e Gerontologia. 4. ed. Rio de Janeiro-RJ: Guanabara Koogan; 2016. p.14-27.

2. Perracini MR, Franco MRC, Ricci NA, Blake C. Physical activity in older people-Case studies of how to make change happen. Best Pract Res Clin Rheumatol. 2017;31(2):260-74.

3. Quiñones AR, Markwardt S, Botoseneanu A. Multimorbidity combinations and disability in older adults. J Gerontol A Biol Sci Med Sci. 2016;71(6):823-30.
4. Oliveira-Figueiredo DST, Felisbino-Mendes MS, Malta DC, Velásquez-Meléndez JG. Prevalência de incapacidade funcional em idosos: análise da Pesquisa Nacional de Saúde Rev Rene. 2017;18(4):468-75.

5. Marandini BAN, Silva BT, Abreu DPG. Functional capacity evaluation of elderly people: activity of the family health strategy teams. J. res. fundam. care. online 2017;9(4):1087-93.

6. Castro DC, Nunes DP, Pagotto V, Pereira LV, Bachion MM, Nakatani AYK. Incapacidade funcional para atividades básicas de vida diária de idosos: estudo populacional. Cien Cuid Saude. 2016;15(1):109-17.

7. Medeiros Rodrigues WK, Vasconcelos Rocha S, Carneiro Vasconcelos LR, de Oliveira Diniz K. Atividade física e incapacidade funcional em idosos da zona rural de um município do Nordeste do Brasil. Rev Bras Promoç Saúde. 2015;28(1):126-32.

8. Medicine ACoS. Diretrizes do ACSM para os testes de esforço e sua presccrição. presccrição. DdApotdees, editor. Rio de Janeiro-RJ: American College of Sports Medicine; 2016.

9. Priario LAA, Carpes FP, Azevedo RR, Nery SB, Ceccon FG, Vieira PRC. Academias da terceira idade: um local para interveção interdisciplinar. Anais do Salão Internacional de Ensino, Pesquisa e Extensão. 2016;7(3).

10. Dantas EHM, Vale RGS. Protocolo GDLAM de avaliação da autonomia funcional. Fit Per J. 2004;3(3):175-82.

11. Vale RGS. Avaliação da autonomia funcional do idoso. Fit Perf J. 2005;4(1):61-72

12. Rikli R e Jones C. Development and validation of a functional fitness test for community residing older adults. J Aging Phys Act. 1999;7(2):129-61.

13. Burton E, Farrier K, Lewin G, Pettigrew S, Hill AM, Airey $P$, et al. Motivators and Barriers for Older People Participating in Resistance Training: A Systematic Review. J Aging Phys Act. 2017;25(2).

14. Cassou ACN, Fermino RC, Santos MS, Rodriguez-Anes CR, Reis RS. Barreiras para a atividade física em idosos: uma análise por grupos focais. Rev Educ Fis 2008;19(3):353-60.

15. Pitanga FJG, Lessa I. Prevalência e fatores associados ao sedentarismo no lazer em adultos. Cad Saude Publica, 2005;21:870-7. 
16. Oliveira DV, Araújo APS, Bertolini SMMG. Capacidade funcional e cognitiva de idosas praticantes de diferentes modalidades de exercícios físicos. Rev Rene. 2015;16(6):872-80.

17. World Health Organization (WHO). Physical activity and older adults: Recommended levels of physical activity for adults aged 65 and above. 2015 [cited Aug 10 2019]. Available from: https://tinyurl.com/ql5scbn

18. Santos RG; Tribess S; Meneguci J; Bastos LLA da G. Damião R., Virtuoso Júnior JS. Força de membros inferiores como indicador de incapacidade funcional em idosos. Motriz. 2013;19(3): S35-S42.

19. Langhammer B, Stanghelle JK. The Senior Fitness Test. J Physiother. 2015;61:163.

20. Bean JF, Kiely DK, LaRose S, O’Neill E, Goldstein R, Frontera WR. Increased velocity exercise specific to task training versus the National Institute on Aging's strength training program: changes in limb power and mobility. J Gerontol A Biol Sci Med Sci. 2009;64:983-91.

21. Vagetti GC, Oliveira V, Silva MP, Pacífico AB, Costa TRA, Campos W. Associação do Índice de Massa Corporal com a aptidão funcional de idosas participantes de um programa de atividade física. Rev Bras geriatr gerontol. 2017;20(2):216-27.

22. Vale RGS, Novaes JS, Dantas EHM. Efeitos do treinamento de força e de flexibilidade sobre a autonomia de mulheres senescentes. R Bras Ci e Mov 2005;13(2):33-40.

23. Vale RGS, Barreto ACG, Novaes JS, Dantas EHM. Efeitos do treinamento resistido na força máxima, na flexibilidade e na autonomia funcional de mulheres idosas. Rev Bras Cineantropom Desempenho Hum. 2006;8:52-8.
24. King AC, Pruitt LA, Phillips W, Oka R, Rodenburg A, Haskell WL. Comparative effects of two physical activity programs on measured and perceived physical functioning and other health-related quality of life outcomes in older adults. J Gerontol A Biol Sci Med Sci. 2000;55(2):M74-M83.

25. Schlicht J, Camaione DN, Owen SV. Effect of intense strength training on standing balance, walking speed, and sit-to-stand performance in older adults. J Gerontol A Biol Sci Med Sci. 2001;56(5):M281-86.

26. Guimarães AC, Rocha CAQC, Gomes ALM, Cader SA, Dantas EHM. Efeitos de um programa de atividade física sobre o nível de autonomia de idosos participantes do programa de saúde da família. Fit Perf J. 2008;7(1):5-9.

27. Matsudo SM, Matsudo VKR e Barros Neto TL. Impacto do envelhecimento nas variáveis antropométricas, neuromotoras e metabólicas da aptidão física. Rev Bras Cien. 2000;8(4):21-32.

28. Concannon LG, Grierson MJ, Harrast MA. Exercise in the older adult: from the sedentary elderly to the masters athlete. PM R. 2012;4(11):833-9.

29. Micheo W, Baerga L, Miranda G. Basic principles regarding strength, flexibility, and stability exercises. PM R. 2012;4(11):805-11.

30. Brito LBB, Ricardo DR, Araujo DSMS, Ramos OS, Myers J, \& Araujo CGS. (2012). Ability to sit and rise from the floor as a predictor of all-cause mortality. Eur J Prev Cardiol. 2014;21(7):892-8.
Received in:11/19/2018

Recebido em: 19/11/2018

Approved in: $11 / 28 / 2019$

Aprovado em: 28/11/2019 